\title{
COVID-19-associated Multisystem Inflammatory Syndrome in Children: A Multicentric Retrospective Cohort Study
}

Bharat Mehra ${ }^{1} \odot$, Mukul Pandey ${ }^{2} \odot$, Dhiren Gupta ${ }^{3} \odot$, Tania Oberoi ${ }^{4} \odot$, Nameet Jerath ${ }^{5} \odot$, Rachna Sharma ${ }^{6} \odot$, Naresh Lal $^{7} \odot$, Chandrasekhar Singha ${ }^{8} \odot$, Bhavana Malhotra ${ }^{9} \odot$, Vinamra Manocha ${ }^{10} \odot$, Ashish $\mathrm{K} \mathrm{Simalti}^{11} \odot$, Yogesh Arya $^{12} \odot$, Sandeep K Dugaya ${ }^{13} \odot$, Swati Kalra ${ }^{14} \odot$, Amar J Chitkara ${ }^{15} \odot$, Anil Sachdev ${ }^{16} \odot$, Neeraj Gupta ${ }^{17} \odot$

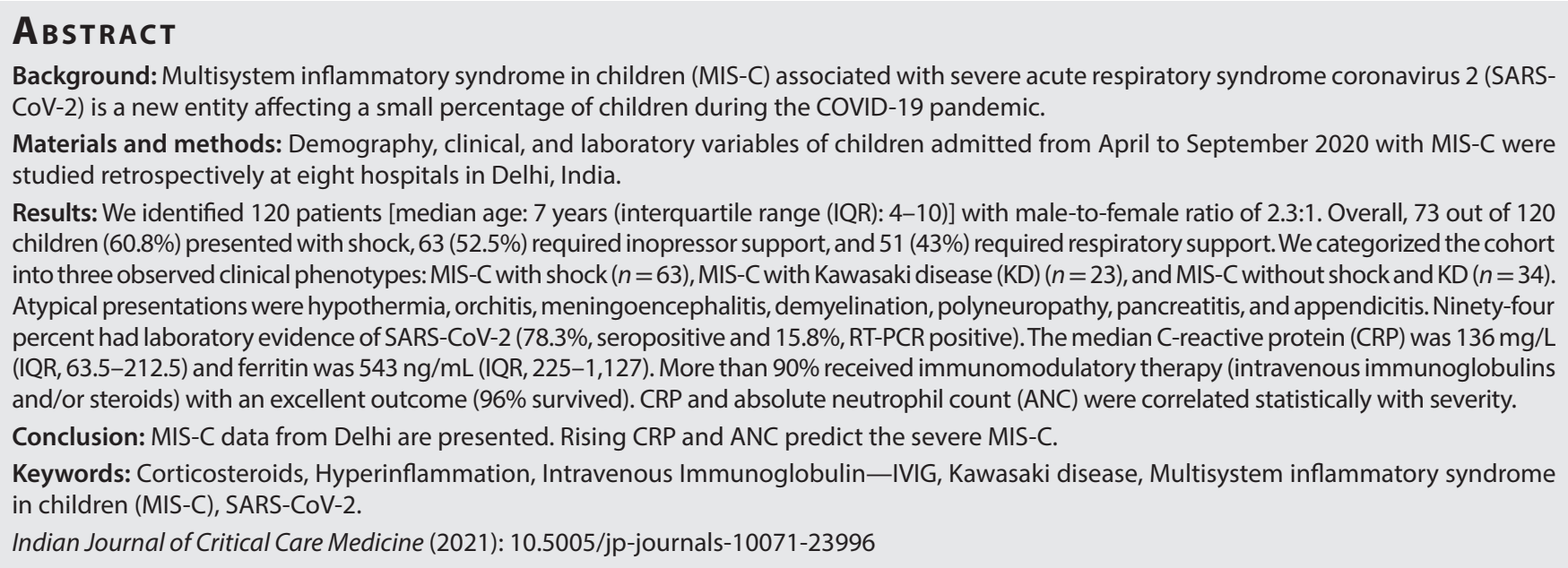

\section{INTRODUCTION}

Multisystem inflammatory syndrome in children (MIS-C) associated with severe acute respiratory syndrome coronavirus 2 (SARS-CoV-2) is a novel entity being reported in children with increasing frequency from countries where the coronavirus disease2019 (COVID-19) pandemic has peaked or fading. ${ }^{1,2}$ Children with this multisystem illness have been described to have overlapping features of Kawasaki disease (KD), toxic shock syndrome, and macrophage activation syndrome. The initial cases from India were reported in May 2020, 3,4 and as the number of COVID-19 cases grew exponentially across the country, clinicians identified this new entity more frequently. In view of the paucity of data from the Asian countries, we conducted this retrospective study with the objective to study the patient characteristics, clinical and laboratory variables, and their analysis for severity prediction.

\section{Study Design and Data Collection}

We conducted a retrospective multicenter cohort study at eight pediatric centers in Delhi, an early epicenter of the COVID-19 pandemic in India. After getting institutional ethical clearance, MIS-C cases were identified retrospectively at each participating site, for the study period from April 1 to September 30, 2020, using Centers for Disease Control and Prevention criteria for MIS-C. ${ }^{2}$ Organ system involvement was defined as described by Feldstein et al. in their study on MIS-C in the United States. ${ }^{5}$ Data were extracted for demographics, clinical presentation, radiological findings, underlying comorbidities, echocardiographic (ECHO) findings, laboratory investigations, treatment modalities, and outcome.
${ }^{1}$ Department of Pediatric Intensive Care, Max Super Speciality Hospital, New Delhi, India

${ }^{2}$ Department of Pediatrics, St Stephens Hospital, New Delhi, India

3,9,16,17 Department of Pediatric Intensive Care, Sir Ganga Ram Hospital, New Delhi, India

4,5 Department of PICU, Apollo Hospital, New Delhi, India

${ }^{6,7}$ Department of Pediatric Critical Care, BLK Super Speciality Hospital, New Delhi, India

${ }^{8,12}$ Department of PICU, Madhukar Rainbow Children's Hospital, New Delhi, India

${ }^{10}$ Department of Pediatrics, Mata Chanan Devi Hospital, New Delhi, India

${ }^{11}$ Department of Pediatric Critical Care, Military Hospital, Dehradun, Uttarakhand, India

${ }^{13,15}$ Department of Pediatrics, Max Super Speciality Hospital, New Delhi, India

${ }^{14}$ Department of Pediatrics, Baba Saheb Ambedkar Hospital, New Delhi, India

Corresponding Author: Bharat Mehra, Department of Pediatric Intensive Care, Max Super Speciality Hospital, New Delhi, India, Phone: +919999538720, e-mail: bharatmehra909@gmail.com

How to cite this article: Mehra B, Pandey M, Gupta D, Oberoi T, Jerath N, Sharma $\mathrm{R}$, et al. COVID-19-associated Multisystem Inflammatory Syndrome in Children: A Multicentric Retrospective Cohort Study. Indian J Crit Care Med 2021;25(10):1176-1182.

Source of support: Nil

Conflict of interest: None

(-) The Author(s). 2021 Open Access This article is distributed under the terms of the Creative Commons Attribution 4.0 International License (https://creativecommons. org/licenses/by-nc/4.0/), which permits unrestricted use, distribution, and non-commercial reproduction in any medium, provided you give appropriate credit to the original author(s) and the source, provide a link to the Creative Commons license, and indicate if changes were made. The Creative Commons Public Domain Dedication waiver (http://creativecommons.org/publicdomain/zero/1.0/) applies to the data made available in this article, unless otherwise stated. 


\section{Statistics}

We described the patient characteristics as numbers and percentages for categorical variables, and median with interquartile range (IQR) for quantitative ones. The Chi-square test was used for assessing the statistical significance of the difference in the percentage of cases with different characteristics between the groups. KruskalWallis test was used for the difference in medians of quantitative data in view of a highly skewed distribution of these measurements. For severity prediction, two models were used, viz. "Binary logistic regression" model and "Random-Forest" model. Receiver operating characteristic (ROC) curves were used to obtain the optimized cutoff value for the score maximizing sensitivity and specificity to distinguish severe and non-severe patients. SPSS 21 was used for calculations.

\section{Results}

Initially, 141 cases were identified. Twenty-one cases were excluded (evidence of other tropical infections along with COVID-19, duplicate patients, detailed investigations not done, and those who expired within 24 hours of hospital stay). Finally, 120 cases were enrolled. The surge of MIS-C cases in our cohort was observed during July and August (Fig. 1), a month after the first surge of acute COVID-19 cases in Delhi, which was observed during the end of May and early June. ${ }^{6}$

\section{Clinical Characteristics, Organ System Involvement, Treatment, and Outcome}

In our cohort, there was a male preponderance (70\%), and the majority $(n=73 ; 61 \%)$ were from 5 to 12 years of age-group (Table 1 ). Twelve children were $<1$ year old, 20 were between 1 and 4 years, and the rest 15 were $>13$ years old. The youngest case of MIS-C was a child of 6 weeks of age. Figure 2 describes the organ system involvement.

The most common symptom was fever (99\%), although one infant presented with severe hypothermia $\left(31^{\circ} \mathrm{C}\right)$ with multi-organ dysfunction. Mucocutaneous involvement was noted in the form of rash (maculopapular, morbilliform, urticarial, and erythroderma), non-purulent conjunctivitis, oral mucositis, and non-pitting edema in hands and feet. We categorized the cohort based on the major clinical phenotype. The first group ( $n=63 ; 52.5 \%$ ) had features of shock during the stay. The second group fulfilled the criteria for KD with or without shock ( $n=23 ; 19.2 \%)$, and the last group had features of multisystem involvement but did not have shock or KD

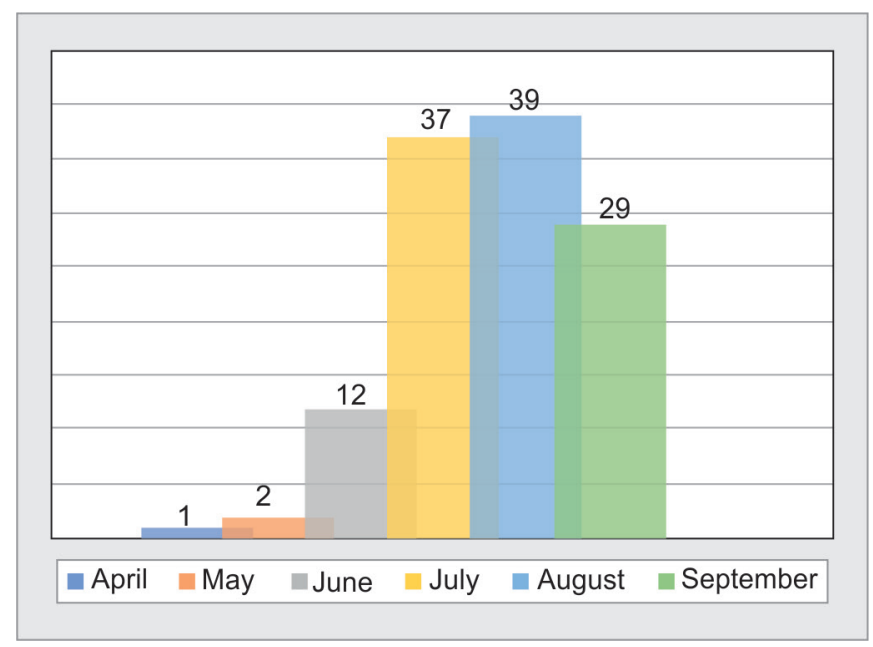

Fig. 1: Month-wise trend of MIS-C cases during COVID-19 pandemic
( $n=34 ; 28.3 \%$ ). Abnormal ECHO findings [such as left ventricular (LV) dysfunction, pericardial effusion, and abnormal coronaries] were observed in 63 patients (58.3\%) out of $108 \mathrm{ECHOs} \mathrm{performed.} \mathrm{Coronary}$ artery dilatation (defined as coronary artery diameter $z$ score $>2)^{7}$ was found in 11 patients. In five patients, it was reported as prominent and echogenic. Acute respiratory distress syndrome (ARDS) was observed in 23 patients (10, RT-PCR positive; 13, antibody positive).

Regarding nervous system involvement, 32 patients had encephalopathy (defined as confusion, irritability, or GCS $<14$ despite correction of shock or hypoxemia). Significant neurological involvement was observed in four patients [one case each of acute disseminated encephalomyelitis, Guillain-Barré syndrome, polyneuropathy, and meningoencephalitis (cerebrospinal fluid and nasopharyngeal swab positive for SARS-CoV-2)]. Ultrasonography of the abdomen was performed in 58 cases, and gall bladder edema with or without sludge was observed in 39 cases. Unusual findings noted were orchitis $(n=1)$, pancreatitis $(n=2)$, and inflamed appendix $(n=2)$.

More than $90 \%$ of cohorts $(110 / 120)$ received some form of immunomodulatory therapy [intravenous immunoglobulins (IV-IG) and/or steroids]. None of the patients in our cohort received biologic agents, such as tocilizumab or anakinra.

The overall outcome was excellent with $96.6 \%$ of survival rate. Among four deaths, two cases were RT-PCR positive, one was antibody positive, and one had the epidemiological link in family. One was an adolescent with acute COVID-19 (positive for RT-PCR)related cytokine release syndrome with severe cardiogenic shock and ARDS, who later succumbed to pancreatitis and peritonitis. Others were: 10-year-old girl from a COVID-19 hotspot (but RT-PCRnegative), who presented with vasoplegic shock, ARDS, and renal failure; a 3-month-old infant with acute COVID-19 related severe ARDS and shock, and last one was a 3-year-old with seizures and acute renal shutdown followed by multi-organ failure.

\section{Laboratory Parameters}

Table 2 describes the values of various laboratory parameters done within first 48 hours of admission. One-hundred and thirteen out of 120 patients had laboratory evidence of exposure to SARS-CoV-2 (94 cases seropositive, 16 cases RT-PCR positive, and 3 patients with both RT-PCR- and antibody positive). Rest seven patients were included based on the epidemiological link (out of these, five could not be tested for antibody as it was not available during that time). All patients had one or more elevated biomarkers of inflammation [C-reactive protein (CRP) and ferritin]. When compared across the three clinical phenotypes, median platelet count and absolute lymphocyte count (ALC) were lower, and the incidence of thrombocytopenia (defined as platelet count $<120 \times 10^{9} / \mathrm{L}$ ) was significantly higher in MIS-C with shock. Similarly, the values of CRP, D-dimer, ferritin, neutrophil-tolymphocyte ratio (NLR), and absolute neutrophil count (ANC) were significantly higher ingroup 1 (MIS-C with shock).

\section{Predictors of Severity}

Among 120 cases, severe MIS-C cases ( $n=71,59 \%)$ were identified as (presence of any of the following):

- Use of inotropes

- Use of invasive or noninvasive ventilation

- ARDS

- Use of renal replacement therapy

Logistic regression analysis of the whole cohort for severity versus age and obesity did not show a statistically significant 
Table 1: Demographic, clinical features, treatment, and outcome of MIS-C cohort

\begin{tabular}{|c|c|c|c|c|c|c|c|c|c|c|}
\hline \multirow{2}{*}{ Clinical variables } & & & & \multicolumn{6}{|c|}{ Clinical phenotype of MIS-C } & \multirow[b]{2}{*}{$p$ value } \\
\hline & & \multicolumn{2}{|c|}{ TOTAL $(n=120)$} & \multicolumn{2}{|c|}{$\begin{array}{l}\text { Group } 1 \text { Shock } \\
\quad(n=63)\end{array}$} & \multicolumn{2}{|c|}{$\begin{array}{c}\text { Group } 2 \text { KD complete } \\
\qquad(n=23)\end{array}$} & \multicolumn{2}{|c|}{$\begin{array}{c}\text { Group } 3 \text { No Shock/KD } \\
(n=34)\end{array}$} & \\
\hline \multicolumn{11}{|l|}{ Demographics } \\
\hline Median age, $y(I Q-R)$ & & 7 & $(4-10)$ & 8 & $(5-10)$ & 4 & $\begin{array}{l}\text { ( } 8 \text { months- } \\
6 \text { years) }\end{array}$ & 7 & $(4-11)$ & 0.002 \\
\hline Males & & 84 & $(70 \%)$ & 42 & $(66.7 \%)$ & 19 & $(82.6 \%)$ & 23 & $(67.6 \%)$ & 0.339 \\
\hline BMI >95th centile & & 34 & $(28.3 \%)$ & 17 & $(27 \%)$ & 4 & $(17.4 \%)$ & 13 & $(38.2 \%)$ & 0.217 \\
\hline Comorbidity & & 8 & $(6.7 \%)$ & 5 & $(7.9 \%)$ & 0 & & 3 & $(8.8 \%)$ & \\
\hline \multicolumn{11}{|c|}{ Clinical features at admission } \\
\hline \multirow{2}{*}{$\begin{array}{l}\text { Fever } \\
\text { duration }\end{array}$} & $<5$ days & 37 & $(30.8 \%)$ & 21 & $(33 \%)$ & 0 & & 13 & $(38.2 \%)$ & \\
\hline & $\geq 5$ days & 82 & $(68.3 \%)$ & 41 & $(65 \%)$ & 23 & $(100 \%)$ & 21 & $(61.8 \%)$ & \\
\hline Gl symptoms & & 86 & (71.7\%) & 48 & $(76.2 \%)$ & 16 & $(69.6 \%)$ & 22 & $(64.7 \%)$ & 0.26 \\
\hline Rash & & 79 & $(65.8 \%)$ & 39 & (61.9\%) & 20 & $(87 \%)$ & 20 & $(58.8 \%)$ & 0.126 \\
\hline Conjunctivitis & & 68 & $(56.6 \%)$ & 31 & $(49.2 \%)$ & 22 & $(95.7 \%)$ & 15 & $(44 \%)$ & 0.326 \\
\hline Shock $^{*}$ & & 73 & $(60.8 \%)$ & 63 & $(100 \%)$ & 10 & (43.5\%) & 0 & & $<0.001$ \\
\hline Respiratory distress & & 52 & $(43.3 \%)$ & 40 & $(63.5 \%)$ & 3 & $(13 \%)$ & 9 & $(26.5 \%)$ & $<0.001$ \\
\hline ARDS $^{@}$ & & 23 & (18.3\%) & 16 & $(25.4 \%)$ & 1 & $(4.3 \%)$ & 6 & $(17.6 \%)$ & 0.078 \\
\hline Abnormal ECHO & & $63 / 108$ & $(58.3 \%)$ & $48 / 63$ & (76.1\%) & $12 / 23$ & $(52.1 \%)$ & $3 / 22$ & $(13.6 \%)$ & \\
\hline • LV dysfunction & & 37 & (30.8\%) & 32 & $(50.8 \%)$ & 4 & $(17.4 \%)$ & 1 & $(2.9 \%)$ & $<0.001$ \\
\hline - CA abnormality & & 16 & $(13.3 \%)$ & 5 & $(7.9 \%)$ & 9 & (39.1\%) & 2 & (5.9\%) & 0.001 \\
\hline - Pericardial effusion & & 15 & $(12.5 \%)$ & 13 & $(20.6 \%)$ & 1 & $(4.3 \%)$ & 1 & $(2.9 \%)$ & \\
\hline Encephalopathy & & 32 & $(26.7 \%)$ & 22 & (34.9\%) & 5 & $(21.7 \%)$ & 5 & $(14.7 \%)$ & 0.454 \\
\hline Seizures & & 7 & $(5.8 \%)$ & 5 & $(7.9 \%)$ & 0 & & 2 & (5.9\%) & 0.072 \\
\hline Acute kidney injury ${ }^{\#}$ & & 27 & $(22.5 \%)$ & 23 & $(36.5 \%)$ & 0 & & 4 & $(11.8 \%)$ & $<0.001$ \\
\hline Abnormal CXR & & 45 & $(37.5 \%)$ & 32 & $(50.8 \%)$ & 2 & $(8.7 \%)$ & 11 & $(32.4 \%)$ & 0.001 \\
\hline - Infiltrate/opacity & & 37 & $(30.8 \%)$ & 26 & $(41.3 \%)$ & 2 & $(8.7 \%)$ & 9 & $(26.5 \%)$ & \\
\hline •Pleural effusion & & 25 & $(20.8 \%)$ & 19 & $(30.2 \%)$ & 1 & $(4.3 \%)$ & 5 & $(14.7 \%)$ & \\
\hline - Pneumothorax & & 1 & & 1 & & 0 & & 0 & & \\
\hline$\geq 4$ Organ system involved & & 70 & $(58.3 \%)$ & 51 & $(81 \%)$ & 10 & $(43.5 \%)$ & 9 & $(26.5 \%)$ & 0.001 \\
\hline \multicolumn{11}{|l|}{ Treatment } \\
\hline PICU care $>48$ hours & & 108 & $(90 \%)$ & 53 & $(84.1 \%)$ & 20 & (86.9\%) & 25 & $(73.5 \%)$ & 0.047 \\
\hline HHFNC/NIV & & 25 & $(20.8 \%)$ & 16 & $(25.4 \%)$ & 2 & $(8.7 \%)$ & 7 & $(20.6 \%)$ & 0.245 \\
\hline $\begin{array}{l}\text { Invasive } \\
\text { ventilation }\end{array}$ & & 26 & $(22.5 \%)$ & 25 & (39.7\%) & 0 & & 1 & $(2.9 \%)$ & $<0.001$ \\
\hline Vasoactive infusion & & 63 & $(52.5 \%)$ & 56 & (88.9\%) & 7 & (30.4\%) & 0 & & $<0.001$ \\
\hline RRT & & 12 & $(8.3 \%)$ & 9 & (14.3\%) & 0 & & 3 & $(8.4 \%)$ & 0.814 \\
\hline ECMO & & 1 & & 1 & & 0 & & 0 & & \\
\hline \multicolumn{11}{|l|}{ Pharmacotherapy } \\
\hline Steroids $>3$ days & & 95 & (79.1\%) & 55 & (87.3\%) & 19 & $(82.6 \%)$ & 21 & $(61.7 \%)$ & \\
\hline IV-IG & & 82 & $(68.3 \%)$ & 44 & (69.8\%) & 22 & (95.7\%) & 16 & $(47.1 \%)$ & \\
\hline No IV-IG/steroids & & 10 & $(8.3 \%)$ & 4 & $(6.3 \%)$ & 0 & 0 & 6 & (17.6\%) & \\
\hline Aspirin & & 36 & $(30 \%)$ & 17 & $(27 \%)$ & 16 & $(69.6 \%)$ & 3 & $(8.8 \%)$ & \\
\hline Enoxaparin/heparin & & 59 & $(49.2 \%)$ & 37 & $(58.7 \%)$ & 19 & $(82.6 \%)$ & 21 & $(61.7 \%)$ & \\
\hline Remdesivir & & 4 & $(3.3 \%)$ & 4 & $(6.3 \%)$ & 0 & & 0 & & \\
\hline \multicolumn{11}{|l|}{ Outcome } \\
\hline Survived todischarge & & 116 & (96.7\%) & 60 & (95.2\%) & 23 & $(100 \%)$ & 33 & (97.1\%) & \\
\hline Death & & 4 & & 3 & & 0 & & 1 & & \\
\hline
\end{tabular}

ARDS, acute respiratory distress syndrome; BMI, body mass index; CA, coronary artery; CXR, chest X-ray; ECMO, extracorporeal membrane oxygenation; ECHO, echocardiography; GI, gastrointestinal; HHFNC, humidified high-flow nasal cannula; IQR, interquartile range; IV-IG, intravenous immunoglobulin; KD, Kawasaki disease; LV, left ventricle; PICU, pediatric intensive care unit; NIV, noninvasive ventilation; RRT, renal replacement therapy. " Shock was defined as requirement of fluid bolus of $\geq 20 \mathrm{~mL} / \mathrm{kg}$ or need for vasoactive medication. ${ }^{\circledR}$ ARDS was defined as per Pediatric Acute Lung Injury Consensus Conference Group (2015). "Acute kidney injury was defined as a creatinine level above the values for age as follows: 1 month $-<1$ year, $0.6 \mathrm{mg} / \mathrm{dL} ; 1-10$ years, $1.05 \mathrm{mg} /$ $\mathrm{dL}_{;} \geq 11$ years, $>1.5 \mathrm{mg} / \mathrm{dL}$ 

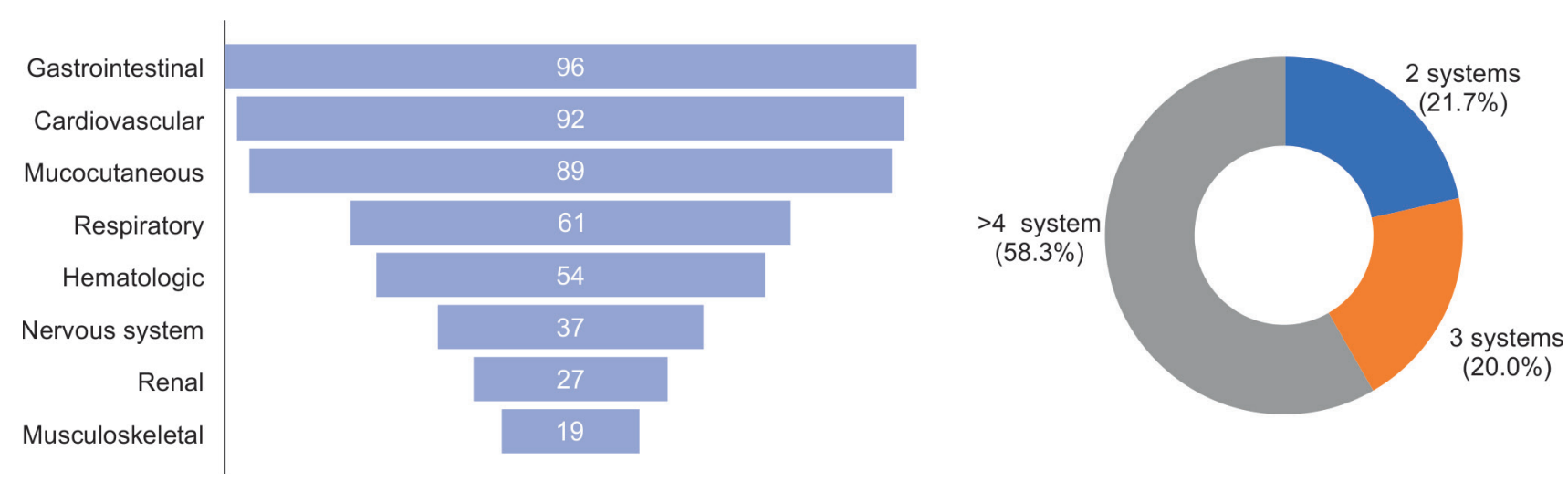

Fig. 2: Organ system involvement of the MIS-C cohort

Table 2: Laboratory parameters of MIS-C cohort

\begin{tabular}{|c|c|c|c|c|c|c|}
\hline & \multirow{2}{*}{\multicolumn{2}{|c|}{ TOTAL $(n=120)$}} & \multicolumn{3}{|c|}{ Clinical phenotype of MIS-C } & \multirow[b]{2}{*}{$p$ value } \\
\hline & & & $\begin{array}{l}\text { Group } 1 \text { Shock } \\
\quad(n=63)\end{array}$ & $\begin{array}{c}\text { Group } 2 \text { KD complete } \\
(n=23)\end{array}$ & $\begin{array}{c}\text { Group } 3 \text { No Shock/KD } \\
(n=34)\end{array}$ & \\
\hline \multicolumn{7}{|l|}{ Evidence of SARS-CoV-2 } \\
\hline Only antibodypositive & 94 & (78.3\%) & (81\%) & (87\%) & (67.6\%) & \\
\hline RT-PCR positive & 19 & $(15.8 \%)$ & $(14.3 \%)$ & $(13 \%)$ & $(20.6 \%)$ & \\
\hline Epidemiological link & 25 & $(20.8 \%)$ & $(19 \%)$ & $(17.4 \%)$ & $(26.5 \%)$ & \\
\hline \multicolumn{7}{|c|}{ Laboratory values in the first 24 hours, median (IQR) } \\
\hline Total leukocyte count, $\times 10^{9} / \mathrm{L}$ & $\begin{array}{l}12.5 \\
(7.5-19.6)\end{array}$ & & $\begin{array}{l}13,100 \\
(7,030-20,500)\end{array}$ & $\begin{array}{l}11.7 \\
(9.0-18.3)\end{array}$ & $\begin{array}{l}9.0 \\
(7-17.8)\end{array}$ & 0.397 \\
\hline $\mathrm{ANC}, \mathrm{x} 10^{9} / \mathrm{L}$ & $\begin{array}{l}9.5 \\
(5.5-15.6)\end{array}$ & & $\begin{array}{l}11.0 \\
(5.7-16.8)\end{array}$ & $\begin{array}{l}9.4 \\
(6.2-12.1)\end{array}$ & $\begin{array}{l}6.8 \\
(3.9-12.3)\end{array}$ & 0.077 \\
\hline $\mathrm{ALC}, / \mu \mathrm{L}$ & $\begin{array}{l}1,912 \\
(892-3,515)\end{array}$ & & $\begin{array}{l}1,500 \\
(862-3,110)\end{array}$ & $\begin{array}{l}2,600 \\
(1,120-4,860)\end{array}$ & $\begin{array}{l}2,200 \\
(820-3,636)\end{array}$ & 0.166 \\
\hline NL ratio (NLR) & $\begin{array}{l}4.6 \\
(2.2-10.1)\end{array}$ & & $\begin{array}{l}6.9 \\
(2.9-11.0)\end{array}$ & $\begin{array}{l}2.8 \\
(1.5-10.4)\end{array}$ & $\begin{array}{l}3.4 \\
(1.9-5.7)\end{array}$ & 0.014 \\
\hline Platelet count, $\times 10^{9} / \mathrm{L}$ & $\begin{array}{l}170 \\
(106-265)\end{array}$ & & $\begin{array}{l}120 \\
(52-206)\end{array}$ & $\begin{array}{l}247 \\
(162-480)\end{array}$ & $\begin{array}{l}195 \\
(158-322)\end{array}$ & $<0.001$ \\
\hline $\mathrm{CRP}, \mathrm{mg} / \mathrm{L}$ & $\begin{array}{l}136 \\
(63.5-212.5)\end{array}$ & & $\begin{array}{l}160 \\
(78-225)\end{array}$ & $\begin{array}{l}113.5 \\
(46.6-196)\end{array}$ & $\begin{array}{l}106 \\
(33.5-161)\end{array}$ & 0.028 \\
\hline Ferritin, $\mathrm{ng} / \mathrm{mL}$ & $\begin{array}{l}543 \\
(225-1,127)\end{array}$ & & $\begin{array}{l}559 \\
(283-977)\end{array}$ & $\begin{array}{l}319.5 \\
(139-651)\end{array}$ & $\begin{array}{l}250 \\
(122-1,204)\end{array}$ & 0.289 \\
\hline D-dimer, $\mathrm{ng} / \mathrm{mL}$ & $\begin{array}{l}2,075 \\
(1,120-5972)\end{array}$ & & $\begin{array}{l}3,230 \\
(1,400-7,034)\end{array}$ & $\begin{array}{l}710 \\
(460-1,900)\end{array}$ & $\begin{array}{l}1,660 \\
(857-6,000)\end{array}$ & 0.002 \\
\hline Thrombocytopenia** $^{*}$ & $43(35.8 \%)$ & & $34(54 \%)$ & $3(13 \%)$ & $6(17.6 \%)$ & $<0.001$ \\
\hline Lymphopenia $^{\#}$ & $51(42.5 \%)$ & & $26(41.3 \%)$ & $11(47.8 \%)$ & $14(41.1 \%)$ & 0.516 \\
\hline $\begin{array}{l}\text { Cardiac marker } \\
\text { elevated }^{@}\end{array}$ & $\begin{array}{l}59 / 104 \\
(56.7 \%)\end{array}$ & & $\begin{array}{l}38 / 55 \\
(67.2 \%)\end{array}$ & $\begin{array}{l}8 / 21 \\
(38.1 \%)\end{array}$ & $\begin{array}{l}13 / 28 \\
(46.4 \%)\end{array}$ & 0.036 \\
\hline ALT>40 IU/L & $\begin{array}{l}64 \\
(53.3 \%)\end{array}$ & & $\begin{array}{l}35 \\
(55.6 \%)\end{array}$ & $\begin{array}{l}7 \\
(30.4 \%)\end{array}$ & $\begin{array}{l}22 \\
(64.7 \%)\end{array}$ & 0.034 \\
\hline INR $>1.1$ & $38(31.7 \%)$ & & $25(39.7 \%)$ & $4(17.4 \%)$ & $9(26.5 \%)$ & 0.068 \\
\hline
\end{tabular}

ALT, alanine aminotransferase; INR, international normalized ratio; NL ratio, neutrophil-to-lymphocyte ratio; RT-PCR, real-time polymerase chain reaction. ${ }^{*}$ Tested for either total antibody or anti-S1- and anti-S2-specific IgG antibody by chemiluminescent immunoassay (CLIA). ${ }^{5}$ Out of total 19 positive for RT-PCR, 3 were also positive for antibody. ${ }^{* *}$ Thrombocytopenia: Platelet count less than $120 \times 10^{9} / \mathrm{L} ;{ }^{*}$ Lymphopenia: Absolute lymphocyte count of less than $1,500 / \mu \mathrm{L}$ in patients 8 months of age or older and of less than $4,500 / \mu \mathrm{L}$ in patients younger than 8 months of age. ${ }^{\circledR}$ Increased cardiac markers (troponin-I, CPKMB, NT-ProBNP) were defined on the basis of the hospital cutoff for the upper limit of the normal range

association. Laboratory parameters (TLC, ANC, ALC, platelet count, CRP, D-dimer and ferritin) were analyzed for severity prediction for 100 patients ( 20 cases got excluded as they were not tested for either ferritin or D-dimer). Two models were used for severity prediction. In the first model (logistic regression), statistically significant $(p<0.05)$ predictors of severity were rising CRP and rising neutrophil count 
(Table 3). In the second model (random forest), CRP was considered as the first split attribute 204 times(out of 322 times $=63 \%$ ) and the second split attribute 308 times and thus was found to be the most significant predictor of severity. The best cutoff for various laboratory parameters was identified using ROC curves (Table 4). Using the results from logistic regression and random forest method, five-node "Classification And Regression Tree" (CART) model was developed to identify the early predictors of severity (Fig. 3).

\section{Discussion}

This study describes the characteristics and outcomes of 120 children with MIS-C admitted to hospitals that serve diverse geographical regions of Delhi. This is so far the largest cohort of MIS-C described from India. Similar to the trends observed in the United States, United Kingdom, and European cohorts of MIS-C, we witnessed the surge of MIS-C a month later to the peak observed in adults. ${ }^{5,8-10}$ This trend further reaffirms the temporal association of this syndrome to SARS-CoV-2.

Whereas in adults, severe COVID-19 is usually observed in second week of illness, MIS-C can occur both during the acute COVID-19 (when RT-PCR comes positive) and 2 to 6 weeks later when the antibodies have been formed. ${ }^{11}$ The latter scenario was much more common in our cohort (78.3\%), and similar findings have been reported across all case series described so far. ${ }^{5,8-10}$ Many of our children who were seropositive did not report any prior COVID-19-like illness in the family or the child. This shows that even asymptomatic COVID-19 infection in children can trigger an immune dysregulation weeks later, resulting in multi-organ dysfunction.

Though the febrile phase precedes the presentation, one infant presented with severe hypothermia and was included in the study because all other clinical and laboratory findings were consistent with MIS-C. Hypothermia at presentation has not been described in any of the previous studies of MIS-C. There is a reported case of a 62-year-old man with COVID-19 who presented with hypothermia and lethargy. ${ }^{12}$ The underlying mechanism could be similar to rare presentation of systemic inflammatory response with hypothermia (instead of fever) in small children.

We observed three clinical phenotypes, although some degree of overlap between the groups can always be argued. The first group (MIS-C shock, 52\%) with hemodynamic instability at presentation was relatively sicker, with a higher incidence of multi-organ dysfunction, with higher use of respiratory and cardiac support. In the UK cohort, the overall shock was observed in $50 \%$ of children, and complete KD was observed in $22.4 \% .{ }^{9}$ Italy reported 30 -fold increase in the incidence of "KD like illness" in children during

Table 3: Logistic regression model for severity prediction

\begin{tabular}{lccc}
\hline & $a O R$ & $(95 \%$ C.I. for aOR) & p value \\
\hline Age (per 1-year increase) & 1.094 & $(0.983-1.218)$ & 0.099 \\
Male gender (reference $=$ female) & 0.300 & $(0.034-2.671)$ & 0.280 \\
Obesity (reference $=$ no obesity) & 2.255 & $(0.862-5.898)$ & 0.097 \\
TLC (per unit increase in $10^{9} / \mathrm{L}$ ) & 1.000 & $(0.999-1.001)$ & 0.787 \\
Neutrophil count (per unit increase in $\left.10^{9} / \mathrm{L}\right)$ & 1.000 & $(1.000-1.001)$ & 0.036 \\
Lymphocyte count (per unit decrease in $\left.10^{9} / \mathrm{L}\right)$ & 1.000 & $(0.999-1.001)$ & 0.167 \\
NL RATIO (per unit increase) & 0.987 & $(0.867-1.123)$ & 0.838 \\
CRP (per unit increase in $\mathrm{mg} / \mathrm{L})$ & 1.007 & $(1.002-1.018)$ & 0.010 \\
Ferritin (per unit increase in $\mathrm{ng} / \mathrm{mL})$ & 1.000 & $(0.999-1.000)$ & 0.450 \\
Platelet count (per unit decrease in $\left.10^{9} / \mathrm{L}\right)$ & 0.997 & $(0.994-1.001)$ & 0.096 \\
D-dimer (per unit increase in $\mathrm{ng} / \mathrm{mL})$ & 1.000 & $(1.000-1.001)$ & 0.554 \\
\hline
\end{tabular}

Table 4: "Best cutoffs coordinates of the Curve" for severity prediction

\begin{tabular}{llccc}
\hline Variable $(\mathrm{s})$ & Value & Sensitivity & 1-specificity & AUC \\
\hline Logistic regression model $(n=100)$ & & & & \\
CRP $(\mathrm{mg} / \mathrm{L})$ & $>138.50$ & 0.710 & 0.237 & 0.742 \\
Ferritin $(\mathrm{ng} / \mathrm{mL})$ & $>217.50$ & 0.903 & 0.658 & 0.597 \\
D-dimer $(\mathrm{ng} / \mathrm{mL})$ & $>2170.00$ & 0.581 & 0.342 & 0.622 \\
TLC $\left(\times 10^{6} / \mathrm{L}\right)$ & $>10085.00$ & 0.710 & 0.395 & 0.635 \\
Neutrophil count $\left(\times 10^{6} / \mathrm{L}\right)$ & $>8387.00$ & 0.710 & 0.342 & 0.684 \\
NL ratio & $>4.150$ & 0.661 & 0.368 & 0.677 \\
Random forest model $(n=100)$ & & & & \\
CRP $(\mathrm{mg} / \mathrm{L})$ & $>115$ & 0.611 & 0.500 & 0.766 \\
Ferritin $(\mathrm{ng} / \mathrm{mL})$ & $>435$ & 0.522 & 0.367 & 0.82 \\
D-dimer $(\mathrm{ng} / \mathrm{mL})$ & $>1,815$ & 0.551 & 0.467 & 0.58 \\
Neutrophil count $\left(\times 10^{6} / \mathrm{L}\right)$ & $>9,500$ & 0.680 & 0.411 & 0.70 \\
Lymphocyte count $\left(\mathrm{x} 10^{6} / \mathrm{L}\right)$ & $<1,965$ & 0.389 & 0.767 & 0.935 \\
NL ratio & $>2.25$ & 0.811 & 0.600 & 0.727 \\
\hline
\end{tabular}




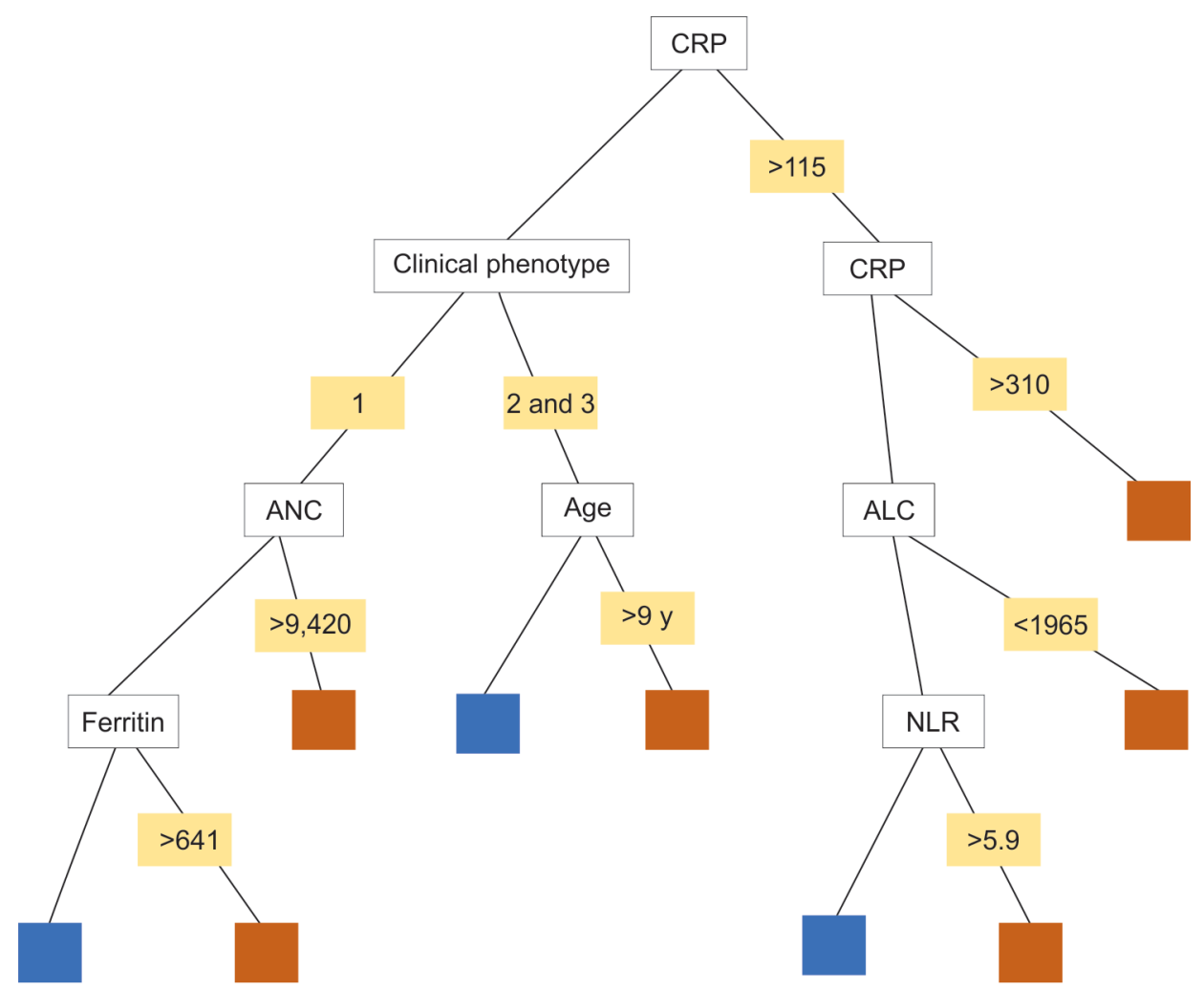

Fig. 3: Five-node CART classification model for severity prediction with splits. Orange squares—severe case; blue squares—non-severe cases

the peak of the COVID-19 pandemic, with $50 \%$ of cases fulfilling complete KD criteria, and shock was present in $50 \%$ of children. ${ }^{8}$ Contrary to the findings in European countries where coronary artery abnormalities were found in around $30 \%$ of children, our study showed lesser involvement of coronaries (13\%), with more of LV dysfunction (31\%). ${ }^{10}$ Small cohorts of pediatric multisystem inflammatory syndrome temporally related to SARS-CoV-2 from Chennai and Mumbai, India, reported coronary involvement in 16 and $26 \%$ of patients, respectively, whereas LV dysfunction was observed in one-third of children in the Mumbai cohort. ${ }^{13,14}$ None of the patients in our cohort had arrhythmia, as compared to $12 \%$ reported in the US cohort. ${ }^{5}$

Unlike adults, only $18 \%$ of our cohort had ARDS. The incidence of ARDS in the spectrum of MIS-C has not been previously reported. The need to highlight this finding is because the chest X-ray (CXR) or computerized tomography findings in MIS-C resemble the late-stage adult COVID-19, with negative results for respiratory pathogens, and they respond very well to the immunomodulatory therapy, particularly steroids. ${ }^{15}$ Serious neurological insult to the nervous system as spectrum of MIS-C, though rare, needs to be highlighted. Abdel-Mannan et al. reported four children with severe MIS-C having encephalopathy with myopathic changes. Neuroimaging revealed lesions in the splenium of the corpus callosum in all patients and T2-hyperintense lesions with restricted diffusion in three children. ${ }^{16}$ Our cohort had four cases of serious neurological involvement, with two cases already published. ${ }^{17,18}$

Literature on severity predictors in MIS-C is scarce till the time of writing this article. Fernandes et al. studied the predictors of severity on 281 children with COVID-19 related respiratory illness and MIS-C. ${ }^{19}$ Their criteria for the severe disease was ICU care
$>48$ hours. In their MIS-C group, lower ALC and increasing CRP were the predictors of severity. Pouletty et al. compared 16 children with KD-like illness following SARS-CoV-2 infection with a historical cohort of "classical" KD and found higher age and high ferritin associated with severe disease. ${ }^{20}$ In our cohort, age and obesity were not associated with severe disease. CRP and neutrophil count served as predictors of severity. The difference in findings could be due to the different criteria used for defining the severity.

\section{Limitations}

Clinical management, laboratory testing protocols, laboratory techniques, and units for reporting of various parameters differed among different centers. Therefore, we may not have captured certain variables uniformly and accurately. For severity prediction, only values taken at admission were measured; however, their values may have changed during the course of illness as the disease progressed.

\section{Conclusion}

The young population is not universally spared from the morbidity of COVID-19 and that even previously healthy children can develop severe disease requiring supportive therapy. The major gain of this study was identifying severity predictors. CRP and ANC are simple laboratory tests that predict the severity.

\section{ACKNOWLegment}

The authors greatly acknowledge the contribution of Ms. Nidhi Mittal in the statistical analysis of data. 


\section{OrCID}

Bharat Mehra (1) https://orcid.org/0000-0001-8194-7623

Mukul Pandey (1) https://orcid.org/0000-0003-4544-7423

Dhiren Gupta 1 https://orcid.org/0000-0002-8244-0768

Tania Oberoi (1) https://orcid.org/0000-0001-5868-268X

Nameet Jerath @ https://orcid.org/0000-0002-1688-3317

Rachna Sharma (1) https://orcid.org/0000-0003-2282-3801

Naresh Lal @ https://orcid.org/0000-0003-1806-3803

Chandrasekhar Singha (1) https://orcid.org/0000-0002-1620-9963

Bhavana Malhotra $\odot$ https://orcid.org/0000-0002-6169-6887

Vinamra Manocha ๑ https://orcid.org/0000-0002-4844-2524

Ashish K Simalti @ https://orcid.org/0000-0002-8227-9038

Yogesh Arya ㄴ) https://orcid.org/0000-0002-4918-7385

Sandeep K Dugaya (ㄴ) https://orcid.org/0000-0003-2154-6144

Swati Kalra ㄴ) https://orcid.org/0000-0002-9714-5710

Amar J Chitkara @ https://orcid.org/0000-0002-7066-8407

Anil Sachdev (1) https://orcid.org/0000-0002-7624-6985

Neeraj Gupta @ 1 https://orcid.org/0000-0002-7131-4985

\section{References}

1. Multisystem inflammatory syndrome in children and adolescents temporally related to COVID-19. Scientific brief: World Health Organization. 2020. Available from: https://www.who.int/news-room/ commentaries/detail/multisystem-inflammatorysyndrome-inchildren-and-adolescents-with covid-19 [Accessed December18, 2020].

2. Multisystem Inflammatory Syndrome in Children (MIS-C) Associated with Coronavirus Disease 2019. Centers for Disease Control and Prevention. Emergency preparedness and response: Health alert network. 2020. Available from: https://emergency.cdc.gov/han/2020/ han00432.asp [Accessed December 15, 2020].

3. Balasubramanian S, Nagendran TM, Ramachandran B, Ramanan AV. Hyper-inflammatory syndrome in a child with COVID-19 treated successfully with intravenous immunoglobulin and tocilizumab. Indian Pediatr 2020;57(7):681-683. DOI: 10.1007/s13312-020-1901-z.

4. Acharyya BC, Acharyya S, Das D. Novel coronavirus mimicking Kawasaki disease in an infant Indian Pediatr 2020;57(8):753-754. DOI: 10.1007/s13312-020-1924-5.

5. Feldstein LR, Rose EB, Horwitz SM, Collins JP, Newhams MM, Son MBF, et al. Multisystem inflammatory syndrome in US. children and adolescents. NEJM 2020;383:334-336. DOI: 10.1056/ NEJMoa2021680.

6. Press Trust of India. Delhi added 64,000 fresh Covid-19 cases in June; 47,489 patients recovered. Business standard. 2020. Available from: https://www.business-standard.com/article/current-affairs/ delhi-added-64-000-fresh-covid-19-cases-in-june-47-489-patientsrecovered-120063001938_1.html.

7. McCrindle BW, Li JS, Minich LL, Colan SD, Atz AM, Takahashi M, et al. Pediatric Heart Network Investigators. Coronary artery involvement in children with Kawasaki disease: risk factors from analysis of serial normalized measurements. Circulation 2007;116(2):174-179. DOI: 10.1161/CIRCULATIONAHA.107.690875.

8. Verdoni L, Mazza A, Gervasoni A, Martelli L, Ruggeri M, Ciuffreda M, et al. An outbreak of severe Kawasaki-like disease at the Italian epicentre of the SARS-CoV-2 epidemic: an observational cohort study. Lancet 2020;395(10239):1771-1778. DOI: 10.1016/S01406736(20)31103-X.

9. Whittaker E, Bamford A, Kenny J, Kaforou M, Jones CE, Shah P, et al. Clinical characteristics of 58 children with a pediatric inflammatory multisystem syndrome temporally associated with SARS-CoV-2.JAMA 2020;324(3):259-269. DOI: 10.1001/jama.2020.10369.

10. Götzinger F, Santiago-García B, Noguera-Julián A, Lanaspa M, Lancella L, Calò Carducci Fl, et al. COVID-19 in children and adolescents in Europe: a multinational, multicentre cohort study. Lancet 2020;4(9):653-661. DOI: 10.1016/S2352-4642(20)30177-2.

11. Kabeerdoss J, Pilania RK, Karkhele R, Kumar TS, Danda D, Singh S. Severe COVID-19, multisystem inflammatory syndrome in children, and Kawasaki disease: immunological mechanisms, clinical manifestations and management. Rheumatol Int 2020;1-14. DOI: 10.1007/s00296-020-04749-4.

12. Allard N, Maruani A, Cret C, Ameri A. Acute hypothermia in Covid-19: a case report. eNeurologicalSci 2020;20:100248. DOI: 10.1016/j.ensci.2020.100248.

13. Dhanalakshmi K, Venkataraman A, Balasubramanian S, Madhusudan M, Amperayani S, Putilibai S, et al. Epidemiological and clinical profile of pediatric inflammatory multisystem syndrome - temporally associated with SARS-CoV-2 (PIMS-TS) in Indian children. Indian Pediatr 2020;57(11):1010-1014. DOI: 10.1007/ s13312-020-2025-1.

14. Jain S, Sen S, Lakshmivenkateshiah S, Bobhate P, Venkatesh S, Udani S, et al. Multisystem Inflammatory Syndrome in Children With COVID-19 in Mumbai, India. Indian Pediatr 2020;57(11):1015-1019. DOI: 10.1007/ s13312-020-2026-0.

15. Winant AJ, Blumfield E, Liszewski MC, Kurian J, Foust A, Lee EY. Thoracic imaging findings of Multisystem Inflammatory Syndrome in Children (MIS-C) associated with COVID-19: what radiologists need to know now. Radiol Cardiothorac Imaging 2020;2(4):e200346. DOI: 10.1148/ryct.2020200346.

16. Abdel-Mannan O, Eyre M, Löbel U, Bamford A, Eltze C, Hameed B, et al. Neurologic and radiographic findings associated with COVID-19 infection in children. JAMA Neurol 2020;77(11):1-6. DOI: 10.1001/jamaneurol.2020.2687.

17. Mehra B, Aggarwal V, Kumar P, Kundal M, Gupta D, Kumar A, Dugaya SK. COVID-19 associated severe multisystem inflammatory syndrome in children with encephalopathy and neuropathy in an adolescent girl with the successful outcome: an unusual presentation. Indian J Crit Care Med 2020;24(12):1276-1278. DOI: 10.5005/ jp-journals-10071-23685.

18. Pandey M. Acute Meningoencephalitis in a Child Secondary to SARSCoV-2 Virus. Indian Pediatr. 2021 Feb 15;58(2):183-184. DOI: 10.1007/ s13312-021-2140-7. PMID: 33632955; PMCID: PMC7926067.

19. Fernandes DM, Oliveira CR, Guerguis S, Eisenberg R, Choi J, Kim M, et al. Severe acute respiratory syndrome coronavirus 2 clinical syndromes and predictors of disease severity in hospitalized children and youth. J Pediatr 2020:S0022-3476(20)31393-7. DOI: 10.1016/j. jpeds.2020.11.016.

20. Pouletty M, Borocco C, Ouldali N, Caseris M, Basmaci R, Lachaume N, et al. Paediatric multisystem inflammatory syndrome temporally associated with SARS-CoV-2 mimicking Kawasaki disease (KawaCOVID-19): a multicentre cohort. Ann Rheum Dis 2020;79(8):999-1006. DOI: 10.1136/annrheumdis-2020-217960. 